\title{
Rumusan Kebijakan Penataan Reklame di Kota Semarang
}

\author{
Formulation of Billboard Arrangement Policy in Semarang City
}

\author{
Rina Kurniati ${ }^{\mathrm{a}}$, Muhammad Fajri Nugraha ${ }^{\mathrm{b} *}$ \\ ${ }^{a}$ Universitas Diponegoro, Semarang, Indonesia \\ ${ }^{b}$ Universitas Diponegoro, Semarang, Indonesia
}

\begin{abstract}
Abstrak
Pesatnya pertumbuhan reklame yang dimanfaatkan sebagai media komunikasi dan pemasaran produk dan jasa, perkembangan tersebut salah satunya disebabkan oleh meningkatnya kebutuhan masyarakat dan adanya desakan pertumbuhan teknologi informasi. Pesatnya pertumbuhan tersebut harus dapat direspon dengan baik oleh Pemerintah Kota Semarang agar poin-poin strategis bagi pendapatan daerah dapat dimaksimalkan sekaligus memaksimalkan upaya penataan ruang di Kota Semarang. Berdasarkan hal tersebut, penelitian ini sendiri bertujuan untuk merumuskan kebijakan penataan reklame di Kota Semarang dengan menggunakan metode deskriptif kualitatif. Upaya perumusan tersebut dilaksanakan dengan melalui beberapa poin analisa yang hasilnya adalah setiap fungsi bangunan dan guna lahan akan mempengaruhi ketentuan terkait penyelenggaraan reklame dan perkembangan penyelenggaraan reklame pada kavling perlu dikendalikan karena berkaitan dengan estetika lingkungan, ruang manfaat jalan dan ruang milik jalan juga dapat diperuntukan untuk iklan dan media informasi asalkan mendapatkan izin dari penyelenggara jalan sesuai kewenangannya.
\end{abstract}

Kata kunci: Reklame, Kebijakan, Kota Semarang

\begin{abstract}
The rapid growth of billboards that are used as a medium of communication and marketing of products and services, one of which is caused by increasing community needs and development of technology \& information. The rapid growth must be responded to well by the Semarang City Government so that strategic points for regional income can be maximized while maximizing spatial planning efforts in Semarang City. Based on this, the research itself aims to formulate a billboard structuring policy in the city of Semarang by using a qualitative descriptive method. The formulation efforts were carried out through several analysis points which resulted in each building function and land use affecting the provisions relating to billboards and the development of advertisement plots on private land to be controlled because they were related to environmental aesthetics, road benefits and road space could also be used for advertising and information media provided that they get permission from the road organizer according to their authority.
\end{abstract}

Keyword: Billboard, Policy, Semarang City

\section{Pendahuluan}

Reklame berfungsi sebagai salah satu media komunikasi dan pada umumnya digunakan sebagai media dalam pemasaran suatu produk/jasa. Namun, dalam perkembangannya reklame juga banyak digunakan Pemerintah sebagai media informasi publik. Keberadaan reklame tersebut terus berkembang hingga saat ini. Perkembangan reklame mengikuti kebutuhan masyarakat dan perkembangan teknologi informasi. Pertumbuhan reklame tersebut dapat dilihat dalam berbagai bentuk dan media yang digunakan. Salah satu fakta yang menunjukkan

\footnotetext{
* Corresponding author. Rina Kurniati

E-mail address: adalerina_66@yahoo.com
} 
pertumbuhan reklame dalam kehidupan sehari-hari adalah tumbuhnya reklame yang terpasang pada kawasan perkotaan baik dalam bentuk spanduk, poster, papan, baliho hingga vidiotron.

Selanjutnya, perkembangan Kota Semarang yang dinamis ini menuntut Pemerintah Kota Semarang tanggap dalam menghadapi perubahan yang ada. Peran Pemerintah Kota Semarang sebagaimana diatur dalam Undang-Undang No.23 Tahun 2014 tentang Pemerintahan Daerah bahwa salah satu Urusan Pemerintahan Wajib yang berkaitan dengan pelayanan dasar meliputi penataan ruang. Penataan ruang tersebut erat kaitannya dengan aktivitas kota yang nantinya berdampak juga terhadap penyelenggaraan reklame di Kota Semarang, apalagi perkembangan aktivitas dan pembangunan yang terjadi di kota Semarang harus responsif terhadap potensipotensi yang dapat memberikan kontribusi untuk pembangunan. Berkaitan dengan hal tersebut ada beberapa wilayah yang memiliki karakteristik khusus yang perlu diperhatikan dalam penentuan kebijakan penyelenggaraan reklame. Adapun Kawasan Khusus tersebut antara lain Kawasan Segitiga Emas, Kawasan White Area, Kawasan Cagar Budaya, Kawasan Akses Bandara, dan kawasan lainnya yang strategis dan potensial.

Kawasan Segitiga Emas yang meliputi Simpang Lima, Jl. Pandanaran, Jl.Gajahmada, dan Jl.Pemuda merupakan kawasan dengan aktivitas ekonomi tinggi. Terlebih lagi dengan Simpang Lima yang merupakan CBD Kota Semarang. Penataan reklame pada kawasan ini tidak hanya untuk kepentingan ekonomi, tetapi juga aspek estetika kawasan. Kawasan White Area meliputi kawasan dengan aktivitas utama adalah perkantoran dan pemerintahan. Kebijakan penyelenggara reklame secara khusus terkait dengan wibawa pemerintah. Selanjutnya untuk Kawasan Cagar Budaya, penyelenggara reklame kebijakan khusus agar sesuai dengan karakteristik aktivitas dan kawasan.

Pemindahan lokasi Bandara Ahmad Yani ke lokasi yang baru membuat jalur akses bandara menjadi kawasan yang potensial untuk penyelenggaraan reklame. Status jalan yang merupakan milik Pemerintah Kota Semarang dapat dijadikan potensi untuk pemungutan retribusi sewa lahan reklame yang dapat meningkatkan Pendapatan Asli Daerah (PAD) Kota Semarang. Penyelenggaraan reklame di kawasan ini harus diperhatikan agar tetap memberikan nilai estetika kawasan, mengingat kawasan akses bandara ini merupakan pintu gerbang Kota Semarang. Kawasan strategis dan potensial seperti kawasan pinggiran kota Semarang juga menjadi lokasi-lokasi yang dapat dimaksimalkan potensinya dalam penyelenggaraan reklame di Kota Semarang. Selain itu, keberadaan reklame di kawasan perbatasan kota Semarang perlu juga diatur penyelenggaraan reklamenya karena berkaitan dengan citra dan identitas Kota Semarang itu sendiri.

Sesuai dengan Peraturan Daerah Kota Semarang No.6 Tahun 2017 tentang Reklame, reklame permanen jenis neon box, billboard, megatron, dan multivision diperbolehkan diselenggarakan di persil/halaman sendiri. Penyelenggaraan reklame di dalam persil/halaman tersebut membuat Pemerintah Kota Semarang tidak dapat lagi memungut retribusi sewa lahan reklame permanen. Hal ini berimbas pada turunnya Pendapatan Asli Daerah (PAD) Kota Semarang. Pelaksanaan perijinan penyelenggaraan reklame dalam Peraturan Daerah Kota Semarang No.6 Tahun 2017 juga dinilai perlu ditinjau kembali agar tidak membutuhkan waktu tunggu yang lama dalam proses administrasinya. Dalam perda tersebut juga masih belum diatur mekanisme pengelolaan barang hasil sitaan pelanggaran reklame dan persyaratan asuransi pembongkaran reklame. Berdasarkan informasi melalui diskusi stakeholder, Peraturan Daerah Kota Semarang No.6 Tahun 2017 ini dinilai cukup menyulitkan para pengusahan penyedia reklame berkaitan dengan tarif dan persyaratan administrasi pengajuan periziinannya.Selain mengatur hal tersebut, Pemerintah Kota Semarang juga bertanggung jawab memberikan pelayanan publik yang prima kepada masyarakat dan memberikan rasa aman dan nyaman bagi masyarakat. Oleh karena itulah penelitian ini bertujuan untuk merumuskan kebijakan penataan reklame di Kota Semarang.

\section{Metode}

Penelitian ini bertujuan untuk merumuskan kebijakan penataan reklame di Kota Semarang. Berdasarkan tujuan tersebut maka penelitian ini menggunakan pendekatan kualitatif yang dalam pendekatan tersebut akan dikaji berbagai data dan fakta yang berkaitan dengan kegiatan reklame di Kota Semarang, hal ini dimaksudkan agar diketahui kebijakan penataan reklame yang paling tepat untuk diterapkan di Kota Semarang. Penelitian ini menggunakan 
metode analisa deskriptif kualitatif karena penelitian deskriptif itu sendiri merupakan penelitian yang berusaha mendeskripsikan suatu gejala, peristiwa, kejadian yang terjadi saat sekarang (Yunus, 2010; Sugiyono, 2014). Penelitian deskriptif memusatkan perhatian kepada masalahmasalah aktual sebagaimana adanya pada saat penelitian berlangsung, melalui penelitian deskriptif, peneliti berusaha mendeskripsikan peristiwa dan kejadian yang menjadi pusat perhatian tanpa memberikan perlakukan khusus terhadap peristiwa tersebut (Yunus, 2010; Sugiyono, 2014). Penelitian deskriptif juga dapat dideskripskan sebagai penelitian yang berusaha untuk menuturkan pemecahan masalah yang ada sekarang berdasarkan data-data, jadi ia juga menyajikan data, menganalisis dan menginterpretasikan.

Teknik pengumpulan data dalam penelitian ini terdiri dari 2 (dua) jenis, yaitu :

a. Survei primer meliputi observasi lapangan dan wawancara

- Observasi lapangan

Observasi lapangan dilakukan dengan pengumpulan data fisik dan juga non fisik terkait kegiatan reklame di Kota Semarang. Hasil dari pengamatan ini dapat digunakan sebagai pendukung hasil analisa dan dapat ditampilkan berupa foto-foto dokumentasi.

- Wawancara

Wawancara dilakukan untuk memperoleh gambaran secara detail mengenai kegiatan reklame di Kota Semarang. Adapun wawancara ini sendiri dilakukan melalui rapat koordinasi, konsultasi, dan dialog dengan OPD terkait yang dikoordinir oleh Dinas Penataan Ruang Kota Semarang, dari teknik ini diharapkan dapat diperoleh data secara komprehensif.

b. Survei sekunder dilakukan dengan melakukan kajian literature atau telaah dokumen. Kajian literatur telaah dokumen ini dapat diperoleh dari jurnal nasional maupun jurnal internasional, buku, skripsi, thesis, hasil penelitian sebelumnya, dan sumber literature atau bahan hukum lainnya yang memiliki sumber terpercaya.

\section{Kajian literatur}

\section{Pengertian Umum dan Karakteristik Reklame}

Reklame adalah benda, alat perbuatan atau media yang menurut bentuk, susunan dan atau corak ragamnya untuk tujuan komersil dipergunakan untuk memperkenalkan, menganjurkan atau memujikan suatu barang, jasa ataupun untuk menarik perhatian umum kepada suatu barang, jasa, seseorang atau badan yang diselenggarakan/ditempatkan atau dapat dilihat, dibaca atau didengar dari suatu tempat oleh umum kecuali yang dilakukan oleh Pemerintah (Jefkins, 1997). Berdasarkan pengertian reklame ini, keberadaan reklame mencakup dua dimensi yang terdiri atas (Djayakusuma, 1982) :

1. Dimensi informasi yang mengandung aspek ekonomi dan bersifat nonfisik. Reklame adalah suatu pesan yang merupakan sarana promosi barang dan jasa dengan menyewa ruang dan waktu dari media luar ruangan.

2. Dimensi keruangan yang mengandung aspek tata ruang dan bersifat fisik. Reklame merupakan suatu benda yang mengisi ruang perkotaan sehingga merupakan bagian dari "aksesoris" perkotaan.

Perkembangan reklame sebagai alat visual yang semakin penting di perkotaan kemudian mendorong perlunya ada perhatian terkait upaya penataan dan penempatan reklame secara tertib seingga penyelenggaran reklame ini tidak hanya berfungsi sebagai promosi di bidang perdagangan akan tetapi dapat pula menciptakan lingkungan yang teratur dan serasi. Penataan reklame itu sendiri erat kaitannya dengan karakteristik dari reklame itu sendiri. Karakteristik reklame tersebut meliputi :

1. Lokasi

Sebagai elemen perancanga kota, papan reklame dapat diletakkan diluar bangunan (bahu jalan, pulau jalan, dan menyatu pada elemen perancangan jalan yang lain), di fasade banguna), di depan bangunan, di arket bangunan maupun di atas bangunan (Eisner, Gallion, \& Eisner, 1993; Shirvani, 1985).

2. Jenis

Jenis ini misalnya dapat berupa papan reklame yang berkelompok secara vertikal maupun horizontal ataupun papan reklame satu, dua, atau tiga sisi (Shirvani, 1985). 


\section{Dimensi}

Dimensi papa reklame ini meliputi ketinggian dan luasan papan reklame. Dimensi papan reklame berpotensi untuk memberi skyline dan fased bangunan maupun kawasan, mempengaruhi aspek kenyamanan pengguna jalan, merupakan sifat papan reklame yang mudah dibaca dari kendaraan yang bergerak (Eisner et al., 1993; Shirvani, 1985).

4. Warna

Pewarnaan berpengaruh sangat besar karena masing-masing warna mempunyai arti tersendiri bagi bangunan-bangunan fisik yang merupakan unsur perancangan kota. Dalam papan reklame menggunakan warna-warna yang ada yaitu merah, jingga, kuning, hijau, biru, nila, maupun ungu. Desain dan warna papan reklame sedemikian rupa sehingga terlihat jelas dan mudah terbaca oleh mata normal manusia (Eisner et al., 1993)

5. Pencahayaan

Pencahayaan adalah suatu sarana bagi pandangan atau penglihatan kita. Pencahayaan mempunyai pengaruh pada sebuah kota khusunya elemen papan reklame terutama pada malam hari karena pencahayaannya dapat dimanfaatkan untuk memberi efek-efek tertentu atau menonjolkan hal-hal tetentu pada satu objek. Pencahayaan pada papan reklame dapat berupa penyiaran pada tulisan (neon sign) ataupun pada bidang papannya (lampu sorot).

\section{Prinsip Perancangan Kota Dalam Karakteristik Reklame}

Penyelenggaraan reklame tidak bisa hanya memperhatikan posisinya terhadap kavlingnya sendiri, hal ini dapat menciptakan dampak berupa disintegratif bentuk-bentuk fisik yang dapat mendorong tidak terciptanya ruang antar bangunan lain. Karenanya dalam penataan reklame harus tetap memegang prinsip-prinsip perancangan kota, seperti kesatuan penampilan, pesan yang sederhana, menggunakan simbol yang relevan, dan menggunakan standar dimensi dan standar warna. Oleh karena itu, sebaiknya reklame tersebut digabung dengan elemen-elemen lain untuk meminimalkan reklame yang berdiri sendiri.

Penentuan konsep penataan reklame harus menggunakan prinsip perancangan kota, antara lain :

1. Identitas

Identitas merupakan kriteria yang memberika ciri atau entitas tersendiri bagi suatu kawasan atau bjek, harus mempunyai suatu hal yang jelas (mudah dikenali, mudah diingat, dan menarik perhatian), atau dengan kata lain identitas tersebut harus memberikan image yang mendalam bagi masyarakat yang menikmati ((Lynch, 1960; Shirvani, 1985).

Upaya penciptaan prinsip identitas dalam karakteristik papan reklame yaitu :

- Pemasangan papan reklame menyatu dengan elemen-elemen perancangan kota. Elemen ini merupakan elemen-elemen penting yang dimanfaatkan. Penyatuan elemen ini akan memberikan image yang tinggi bagi masyarakat (Shirvani, 1985; Sprereigen, 1965). Elemen tersebut antara lain elemen perancangan jalan, elemen sculpture, bangunan-bangunan komersial dan ruang terbuka yang berupa taman.

- Penggunaan jenis papan reklame tidak statis, untuk menghindari kesan monoton. (Shirvani, 1985). Seperti papan reklame di stadion sepakbola yang tampilannya selalu berubah. Penggunaan jenis papan reklame ini hanya dapat diterapkan di beberapa papan reklame. Seperti papan reklame yang berdiri sendiri dengan dimensi kecil, papan reklame diruang terbuka dan papan reklame di beberapa signifikan objek (seperti halte bus, jembatan penyebrangan, kotak telpon deret).

- Pencahayaan pada reklame dapat menciptakan kesan berbeda dengan kawasan lain, khususnya pada malam hari, seperti pencahayaan papan reklame berupa lampu "flip-flop".

2. Views

Views Merupakan karakteristik yang berhubungan dengan aspek kejelasan dan kemudahan untuk orientasi penglihatan dan persepsi manusia terhadap ukuran dan bentuk, warna secara material bangunan fisik baik secara individu maaupun secara lingkungan (urban space) (Eckbo, 1969; Shirvani, 1985). Jadi konsep dari prinsip view ini pada dasarnya adalah aspek kejelasan pandangan manusia. 
Upaya penciptaan prinsip view dalam karakteristik papa reklame diantaranya adalah

- Penggunaan papan reklame yang sisi-sisinya sesuai dengan lokasi pemasangan dan sirkulasi lalu lintas. Pemasangan papan reklame ini dapat efisien dalam pemanfaatan titik-titik lokasi pemasangan papa reklame dan dalam pemanfaatan ruang serta efektif dalam memasarkan produk.

- Pemasangan papan reklame secara berkelompok vertikal dan horizontal. Pemasangan papan reklame jenis ini dapat efisien dalam pemanfaatan ruang bagi pemasangan papan reklame.

- Pemasangan papan reklame pada sudut kota yang strategis, pada pulau jalan (baik yang terletak di tengah simpul, dititik temu antara koridor jalan dengan simpul, di tengah koridor jalan maupun disebelah kiri dan kanan koridor jalan), pada bangunan (fased, arked, kanopi, depan dan atas), pada beberapa significant objects serta pada daerah yang bertopografi tinggi

\section{Penyelenggaraan Reklame}

1. Perizinan

Berkaitan dengan pemasangan reklame yang merupakan salah satu bentuk pemanfaatan ruang, perizinan merupakan sesuatu yang dipertimbangkan dalam pengendalian pemanfaatan ruang (UU No.26 Tahun 2007 tentang Penataan Ruang). Penyelenggaraan mekanisme perizinan yang efektif akan mempermudah pengendalian pembangunan dan penertiban pelanggaran rencana tata ruang. Bila mekanisme perizinan tidak diselenggarakan dengan baik, maka akan menimbulkan penyimpangan pemanfaatan ruang secara legal. Mekanisme perizinan juga dapat dimanfaatkan sebagai perangkat insentif untuk mendorong pembangunan yang sesuai dengan rencana tata ruang, atau perangkat disinsentif untuk menghambat pemanfaatan ruang yang tidak sesuai dengan rencana tata ruang.

2. Pengawasan

Pengawasan adalah merupakan proses serangkaian kegiatan untuk menjamin agar seluruh rencana dapat dilaksanakan dan pelaksanannya sesuai dengan apa yang direncanakan (Widiyanti \& Sunindhia, 1987). Dikaitkan dengan pemasangan media reklame luar ruangan yang diartikan sebagai salah satu bentuk pemanfaatan ruang, maka pengawasan dalam hal ini dapat diartikan sebagai kegiatan pengawasan pemanfaatan ruang.

3. Penertibam

Penertiban dalam pemanfaatan ruang adalah usaha atau kegiatan untuk mengambil tindakan agar pemanfaatan ruang sesuai rencana dapat terwujud. Kegiatan penertiban dapat dilakukan dalam bentuk penertiban langsung dan penertiban tidak langsung. Penertiban langsung dilakukan melalui mekanisme penegakan hukum berdasarkan peraturan perundang-undangan yang berlaku. Sementara itu, penertiban tidak langsung dilakukan dalam bentuk sanksi disinsentif, antara lain melalui pengenaan retribusi secara progresif atau membatasi penyediaan sarana dan prasarana lingkungannya. Bentuk-bentuk pengenaan sanksi yang berkenaan dengan penertiban antara lain: sanksi administratif, sanksi perdata dan sanksi pidana.

\section{Hasil dan Pembahasan}

\section{Analisa Fungsi Bangunan}

Analisa fungsi bangunan ini diharapkan dapat memberikan gambaran fungsi bangunan gedung yang dapat menjadi tempat bagi media reklame. Kajian fungsi bangunan gedung didasarkan atas pembagian fungsi berdasarkan pada Undang-undang No. 28 Tahun 2002 tentang Bangunan Gedung. dalam undang-undang tersebut diuraikan bahwa fungsi bangunan gedung terdiri 6 kelompok besar yaitu :

1. Bangunan gedung fungsi hunian meliputi bangunan untuk rumah tinggal tunggal, rumah tinggal deret, rumah susun, dan rumah tinggal sementara.

2. Bangunan gedung fungsi keagamaan meliputi bangunan gedung untuk masjid (termasuk mushola), gereja (termasuk kapel), pura, wihara, dan kelenteng. 
3. Bangunan gedung fungsi usaha meliputi bangunan gedung untuk perkantoran (perkantoran swasta), perdagangan, perindustrian, perhotelan, wisata dan rekreasi, terminal (bandara, pelabuhan, stasiun KA, terminal bis), dan penyimpanan (gudang).

4. Bangunan gedung fungsi sosial budaya meliputi bangunan gedung untuk perkantoran pemerintah, pendidikan, kebudayaan, pelayanan kesehatan, laboratorium, dan pelayanan umum.

5. Bangunan gedung fungsi khusus meliputi bangunan gedung untuk reaktor nuklir, instalasi pertahanan dan keamanan, dan bangunan sejenis yang diputuskan oleh menteri.

6. Bangunan gedung fungsi campuran, satu bangunan gedung dapat memiliki lebih dari satu fungsi, misal rumah toko, rumah kantor, dan rumah industri.

Berikut penempatan reklame pada beberapa fungsi bangunan yang sudah ada di Kota Semarang :

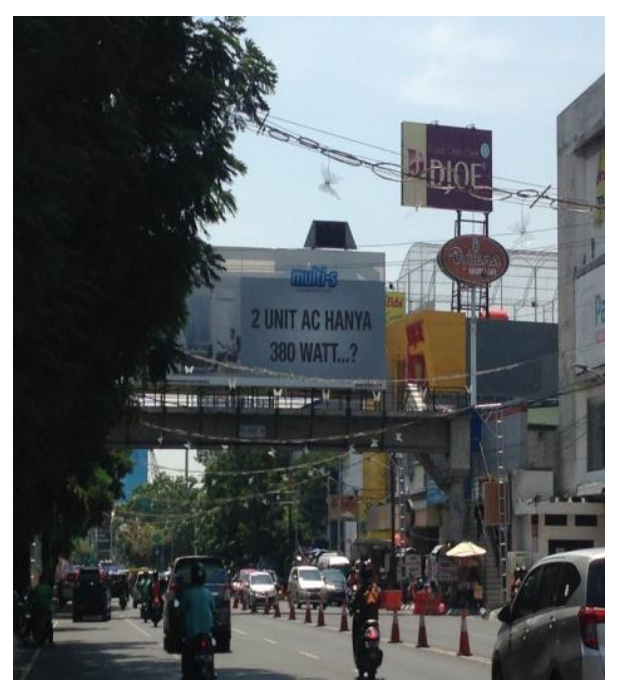

Gambar 1 Reklame di Kawasan Usaha Segitiga Emas (Dokumentasi Penulis, 2018)
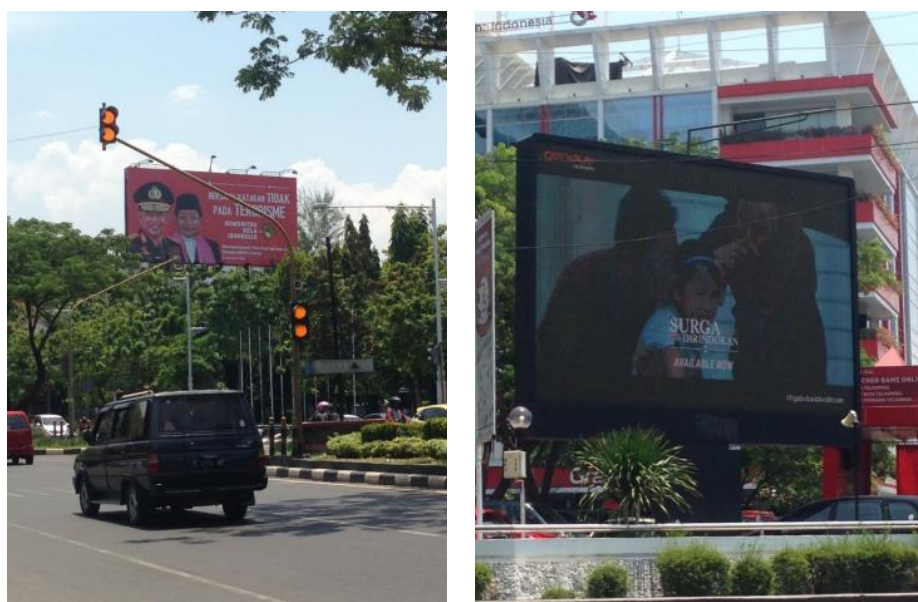

Gambar 2 Reklame di Kawasan Pemerintahan (Dokumentasi Penulis, 2018) 

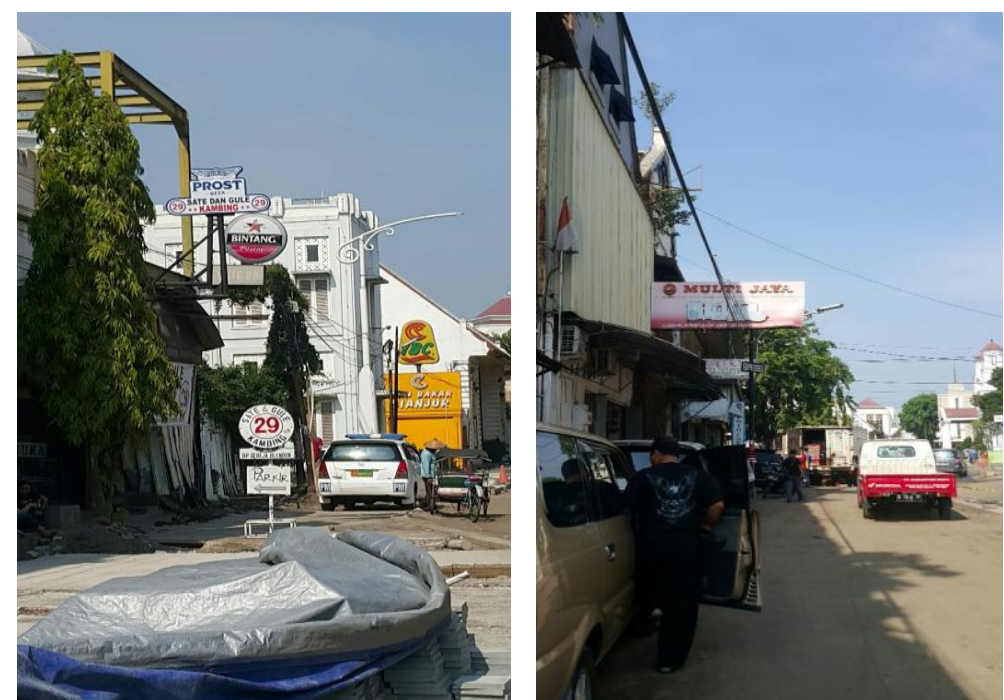

Gambar 3 Reklame di Kawasan Cagar Budaya (Dokumentasi Penulis, 2018)
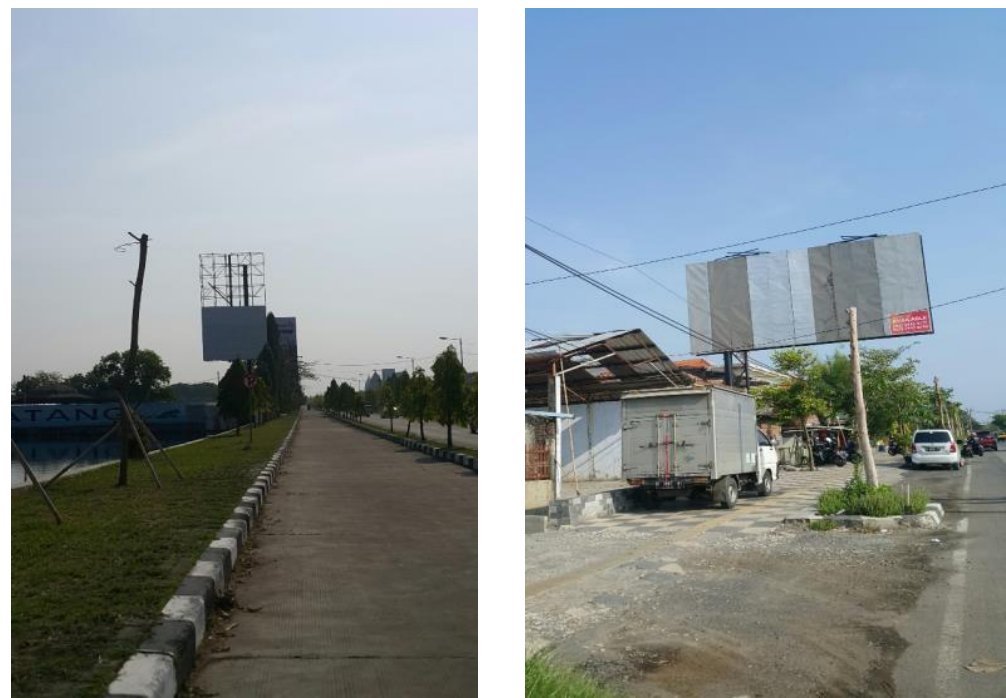

Gambar 4 Reklame di Akses Bandara Baru (Dokumentasi Penulis, 2018)

Analisa fungsi bangunan ini ditujukan untuk mengkaji tujuan dan esensi bangunan tersebut yang dikaitkan dengan peran media reklame terhadap fungsi tersebut untuk dapat diketahui tingkat kelayakan penempatan media reklame dalam bangunan. untuk lebih jelasnya dapat dilihat pada tabel di bawah ini.

Tabel 1 Tingkat Kelayakan Penempatan Reklame (Analisa Penulis, 2016)

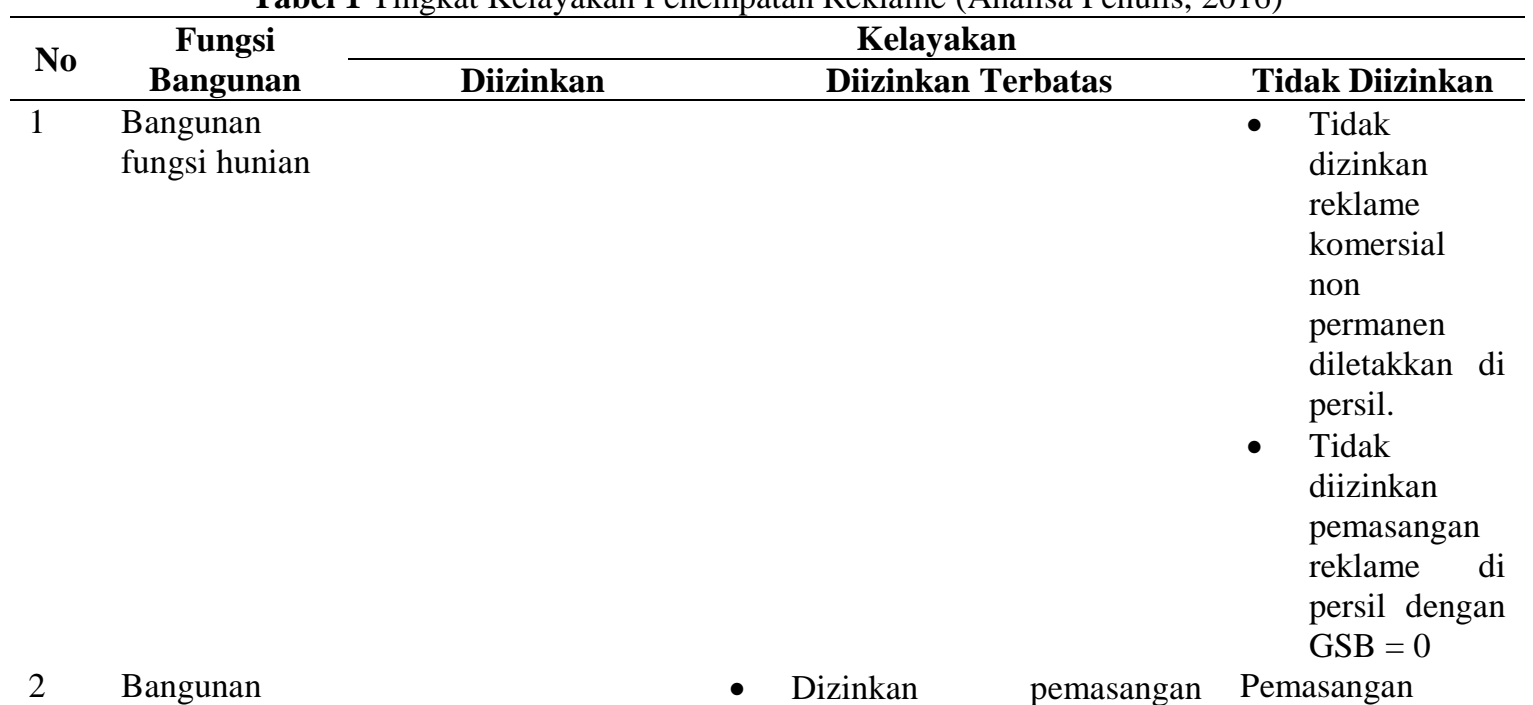


fungsi

keagamaan

Bangunan fungsi usaha

Bangunan fungsi sosial budaya

\section{Bangunan} fungsi khusus
- Pemasangan reklame komersial dan non komersial permanen dapat diletakkan dinding, atap maupun $\mathrm{d} i$ persil.

- Pemasangan reklame di persil harus mempertimbangka $\mathrm{n}$ luas pekarangan atau jarak bangunan dengan pagar.

Dizinkan pemasangan reklame komersial dan non komersial permanen dan non permanen dapat diletakkan di atap, dinding dan persil apabila bangunan gedung milik swasta. reklame komersial dan non komersial baik permanen dan non permanen diletakkan $\mathrm{d}$ persil.

- Reklame komersial permanen dilakukan secara terbatas baik dari segi jumlah maupun ukurannya.

Bangunan gedung yang berada di Tidak diizinkan kawasan khusus perlu mempertimbangkan persyaratan bangunan gedung dan kawasan dalam pemasangan reklame reklame di persil dengan $\mathrm{GSB}=0$ pemasangan reklame di persil dengan GSB =0
Diizinkan pemasangan reklame non komersial baik permanen maupun non permanen pada bangunan pemerintah di persil
- $\quad$ Tidak dizinkan reklame komersial non permanen diletakkan di persil.

- Tidak diizinkan pemasangan reklame di persil dengan $\mathrm{GSB}=0$

Tidak

diperbolehkan untuk pemasangan media reklame baik di dinding, atap maupun di persil.

Tidak diperbolehkan memasang reklame komersial dan non komersial baik permanen maupun non permanen di atap.
7. Bangunan fungsi campuran skala besar
Diizinkan pemasangan media reklame komersial dan non komersial serta permanen maupun non permanen di dinding, dan persil.

Diizinkan pemasangan media reklame komersial dan non komersial serta permanen maupun non permanen di atap, dinding, dan persil. 


\section{Analisa Estetika Kota Terhadap Peletakan Reklame}

Kota tidak terlepas dari papan reklame. Media ruang luar sebagai salah satu cara promosi yang efektif telah berkembang diberbagai sudut kota, baik yang legal maupun yang ilegal. Fenomena perkembangan media ruang luar tidak hanya memanfaatkan ruang publik, melainkan telah memanfaatkan ruang privat dalam hal ini bangunan dan tapaknya. Fenomena media ruang luar yang berkembang dalam bangunan dan tapaknya perlu dikaji karena keberadaan media ruang luar yang berada di lingkungan tapak dan bangunan dianggap sebagian orang adalah sesuatu yang sah karena berada di lingkungan kepemilikan privat, bukan di area publik sehingga dapat dilakukan secara bebas oleh pemilik gedung. Hal ini dapat mempengaruhi pada menurunnya kualitas estetika ruang kota apabila tidak diatur dengan baik. Contoh penempatan media ruang luar pada kavling privat :
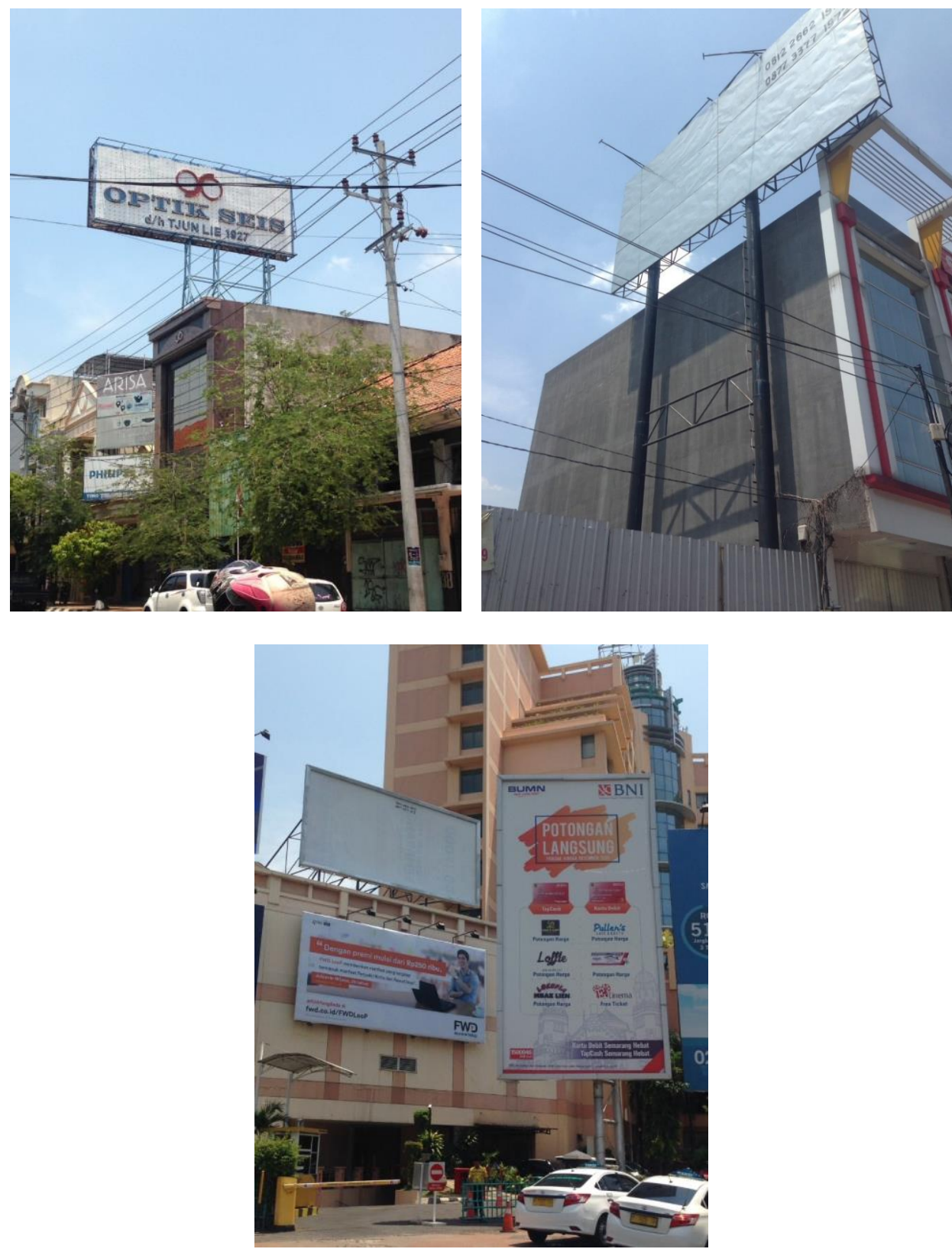

Gambar 5 Penempatan Media Ruang Luar Reklame Pada Kavling Privat (Dokumentasi Penulis, 2018)

Bahwasanya ditinjau dari kepemilikan, bangunan dan tapaknya merupakan lahan yang dimiliki secara sah oleh pemiliknya yang bersifat perorangan atau organisasi. Kepemilikan ini memberikan kewenangan terhadap pemiliknya untuk mengelola dan menata lingkungan didalam tapaknya. Tapak merupakan lahan yang bersifat privat karena penggunaan dan kewenangan pengaturannya dilakukan oleh perorangan bukan diatur secara bersama oleh masyarakat melalui kesepakatan bersama. Hal ini yang membedakan hak privat dengan hak 
publik. Hak privat diterapkan didalam ruang yang bersifat privat, sedangkan hak publik diterapkan didalam ruang publik. Bangunan arsitektural mempunyai peran dalam membentuk estetika lingkungan melalui wajah bangunan yang secara bersamaan menjadi wajah kota. Estetika wajah kota sangat dipengaruhi oleh visual oleh pengamat dalam hal ini adalah masyarakat kota tersebut. Visualisasi tidak dapat dibatasi oleh batas kepemilikan perseorangan dan atau kepemilikan masyarakat. Oleh karena itu, perwujudan bangunan tidak hanya untuk kepentingan privat melainkan juga untuk kepentingan publik.

\section{Analisa Kelas Jalan dan Guna Lahan}

Analisa kelas dan hirarki jalan menentukan layak dan tidak layaknya media didalam persil. Hal ini dimaksudkan dengan lebar jalan yang sempit akan berpengaruh terhadap estetika ruang luarnya. Kelas jalan dapat menentukan lebar jalan. Lebar jalan di bawah 12 meter apabila didirikan media reklame diatas bangunan akan mengurangi kualitas lingkungan. Lebar jalan yang berada di bawah 12 meter hanya diperuntukkan media yang berada di persil dan menempel di dinding bangunan. Selain itu, menurut peraturan perundang-undangan yang berlaku juga diatur bahwasannya ruang milik jalan dan ruang manfaat jalan dapat dimanfaatkan selain peruntukan utamanya yaitu misal untuk peruntukan iklan dan media informasi, dengan kewajiban untuk mendapatkan izin dari penyelenggara jalan sesuai kewenangannya. Berikut analisa peruntukan reklame berdasarkan matriks kombinasi jalan dan guna lahan :

Gambar 6 Matriks Kombinasi Jalan dan Guna Lahan (Analisa Penulis, 2016)

\begin{tabular}{|c|c|c|c|c|c|c|c|}
\hline \multirow[b]{2}{*}{ No } & \multirow[b]{2}{*}{ Guna Lahan } & \multicolumn{6}{|c|}{ Kelas } \\
\hline & & $\begin{array}{c}\text { Jalan } \\
\text { Tol }\end{array}$ & $\begin{array}{c}\text { Arteri } \\
\text { Primer }\end{array}$ & $\begin{array}{c}\text { Arteri } \\
\text { Sekunder }\end{array}$ & $\begin{array}{l}\text { Kolektor } \\
\text { Primer }\end{array}$ & $\begin{array}{l}\text { Kolektor } \\
\text { Sekunder }\end{array}$ & Lokasl \\
\hline 1. & Industri rumah tangga kecil & & & & & & \\
\hline 2. & Pariwisata budaya & & & & & & \\
\hline 3. & Perdagangan dan jasa & & & & & & \\
\hline 4. & Perkantoran & & & & & & \\
\hline 5. & Kawasan perlindungan setempat & & & & & & \\
\hline 6. & Kawasan sekitar danau/waduk & & & & & & \\
\hline 7. & $\begin{array}{l}\text { Kawasan Perumahan Kepadatan } \\
\text { Rendah }\end{array}$ & & & & & & \\
\hline 8. & $\begin{array}{l}\text { Kawasan Perumahan Kepadatan } \\
\text { Sedang }\end{array}$ & & & & & & \\
\hline 9. & $\begin{array}{l}\text { Kawasan Perumahan Kepadatan } \\
\text { Tinggi }\end{array}$ & & & & & & \\
\hline 10 & $\begin{array}{l}\text { Kawasan Peruntukan Hutan } \\
\text { Produksi Tetap }\end{array}$ & & & & & & \\
\hline 11. & Campuran & & & & & & \\
\hline $\begin{array}{l}12 . \\
13 . \\
14 .\end{array}$ & $\begin{array}{l}\text { Militer } \\
\text { Olahraga } \\
\text { Pelayanan Umum }\end{array}$ & & & & & & \\
\hline 15. & Perikanan & & & & & & \\
\hline 16. & Pertambangan & & & & & & \\
\hline 17. & Transportasi & & & & & & \\
\hline 18. & Pertanian & & & & & & \\
\hline 19. & Ruang Terbuka Hijau & & & & & & \\
\hline
\end{tabular}

\section{Keterangan :}

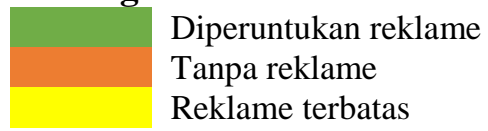

\section{Kesimpulan}

Dalam penataan reklame ada banyak pertimbangan yang perlu diperhatikan, seperti kelas jalan, guna lahan, estetika kawasan, dan sebagainya. Setiap fungsi bangunan juga turut mempengaruhi ketentuan terkait penyelenggaraan reklame, contohnya adalah ada perbedaa perlakuan antara bangunan fungsi usaha dengan bangunan fungsi hunian. Selain itu, perkembangan reklame sebagai media ruang luar yang banyak saat ini diselenggarakan pada 
kavling privat juga perlu diatur karena berkaitan estetika lingkungan, karena pada dasarnya perwujudan bangunan tidak hanya mempengaruhi kepentingan privat melainkan juga untuk kepentingan publik berupa visualisasi kawasan. Ruang manfaat jalan dan ruang milik jalan juga dapat dimanfaatkan diluar peruntukan utamanya misalkan untuk peruntukan iklan dan media informasi, asalkan mendapatkan izin dari penyelenggara jalan sesuai kewenangannya.

\section{Referensi}

Djayakusuma, T. (1982). Periklanan. Bandung: Armico.

Eckbo, G. (1969). The Landscape of Tourism. Landscape.

Eisner, S., Gallion, A., \& Eisner, S. (1993). The Urban Pattern. John Willey \& Sons.

Jefkins, F. (1997). Periklanan. Jakarta: Erlangga.

Lynch, K. (1960). The Image of City. MIT Press.

Peraturan Daerah Kota Semarang Nomor 6 Tahun 2017 tentang Reklame

Shirvani, H. (1985). The Urban Design Process. New York: Van Nostrand Reinhold. Co.

Sprereigen, P. D. (1965). Urban Design: The Architecture of Town and Cities. Mc Graw - Hill Book, Co. Sugiyono. (2014). Metode Penelitian Kuantitatif, Kualitatif dan R\&D. Bandung: Alfabeta.

Undang-undang Nomor 26 Tahun 2007 tentang Penataan Ruang

Widiyanti, N., \& Sunindhia, Y. W. (1987). Kepala Daerah dan Pengawasan dari Pusat. Jakarta: PT. Bina Aksara.

Yunus, H. S. (2010). Metode Penelitian Wilayah Kontemporer. Yogyakarta: Pustaka Pelajar. 